\title{
Reactive oxygen species involved in trichosanthin-induced apoptosis of human choriocarcinoma cells
}

\author{
Chun-yang ZHANG*, Yi-xuan GONG†, Hui MA* ${ }^{* 1}$, Cheng-cai $A N \dagger$ and Die-yan $\mathrm{CHEN}^{*}$ \\ *Molecular and Nano Sciences Laboratory, Department of Physics, Tsinghua University, Beijing 100084, China, and †National Laboratory of Protein Engineering and \\ Plant Genetic Engineering, College of Life Sciences, Peking University, Beijing 100871, China
}

The type-I ribosome-inactivating protein trichosanthin (TCS) has a broad spectrum of biological and pharmacological activities, including abortifacient, anti-tumour and anti-HIV activities. We have found for the first time that TCS stimulated the production of reactive oxygen species (ROS) in JAR cells (a human choriocarcinoma cell line) in a time- and concentrationdependent manner by using the fluorescent probe $2^{\prime}, 7^{\prime}$ dichlorofluorescein diacetate with confocal laser scanning microscopy. ESR spectral studies and the inhibition of ROS formation by the superoxide radical anion $\left(\mathrm{O}_{2}^{-\cdot}\right)$ scavenger superoxide dismutase, the $\mathrm{H}_{2} \mathrm{O}_{2}$ scavenger catalase and the hydroxyl radical $\left(\mathrm{OH}^{*}\right)$ scavenger mannitol suggested the involvement of $\mathrm{O}_{2}^{-\bullet}, \mathrm{H}_{2} \mathrm{O}_{2}$ and $\mathrm{OH}^{*}$. TCS-induced ROS formation was shown to be dependent on the presence of both extracellular and intracellular $\mathrm{Ca}^{2+}$; moreover, ROS production paralleled the intracellular $\mathrm{Ca}^{2+}$ elevation induced by TCS, suggesting that ROS production might be a consequence of $\mathrm{Ca}^{2+}$ signalling. TCS-induced activation of caspase- 3 was initiated within $2 \mathrm{~h}$; however, TCS-induced production of ROS was initiated within 5 min, suggesting that the production of ROS preceded the activation of caspase-3. Simultaneous observation of the nuclear morphological changes via two-photon laser scanning microscopy and ROS production via confocal laser scanning microscopy revealed that ROS is involved in the apoptosis of JAR cells. The involvement of ROS was also confirmed by the inhibition of TCS-induced cell death by the antioxidant Trolox and the ROS scavengers catalase and mannitol. Diethylenetriaminepenta-acetic acid, an inhibitor of metal-facilitated $\mathrm{OH}^{*}$ formation, markedly inhibited TCS-induced cell death, suggesting that TCS induced $\mathrm{OH}^{*}$ formation via the Fenton reaction. The finding that ROS is involved in the TCS-induced apoptosis of JAR cells might provide new insight into the antitumour and anti-HIV mechanism of TCS.

Key words: calcium, caspase-3, hydrogen peroxide, hydroxyl radical, superoxide radical anion.

\section{INTRODUCTION}

Apoptosis is a form of cellular suicide that ensures that superfluous or harmful cells are eliminated from multicellular organisms [1,2]. Apoptosis is distinguished from necrosis by characteristic morphological and biochemical changes, including compaction and fragmentation of the chromatin, plasma membrane blebbing and cell shrinkage, the activation of certain proteases and nucleases, and cytoskeleton breakdown [1-3]. Apoptosis begins with the condensation of nuclear chromatin at the nuclear periphery, followed by blebbing of the nuclear and cytoplasmic membranes, and culminates in the fragmentation of residual nuclear structures into discrete membrane-bounded apoptotic bodies [1-3]. Apoptosis occurs in many different cell types and in response to diverse stimuli [2]. Apoptosis is now considered to be an essential cellular response to agents used for anti-tumour chemotherapy and radiotherapy.

Reactive oxygen species (ROS) are oxygen-centred molecules such as the superoxide radical anion $\left(\mathrm{O}_{2}^{-\cdot}\right), \mathrm{H}_{2} \mathrm{O}_{2}$ and the hydroxyl radical $\left(\mathrm{OH}^{*}\right)$. ROS can be generated in cells as a byproduct of cellular metabolism or in response to chemical insult. ROS have many roles in normal and pathological process; they are implicated in the initiation of tumours [4], in ageing [5] and in a wide range of neuropathologies including Alzheimer's disease and Parkinson's disease. Accumulating evidence has pointed to ROS as being second messengers in the activation of enzymes, transcription factors, growth, differentiation and apoptosis [6-9].

Trichosanthin (TCS), a $27 \mathrm{kDa}$ ribosome-inactivating protein ('RIP') extracted from the root tuber of a traditional Chinese medicinal herb Trichosanthes kirilowiii, has been used for more than 1000 years in China to induce abortion owing to its high toxicity to trophoblasts. There is increasing evidence to suggest that TCS has a broad spectrum of biological and pharmacological activities, including abortifacient and anti-tumour activities [10-13]. Recent studies have shown that TCS possesses strong anti-HIV activity; TCS inhibits the replication of HIV-1 in vitro and decreases HIV markers in vivo [14-18]. So far, good progress has been made with the elucidation of the anti-tumour and antiHIV mechanism of TCS, including the observation that Nterminal sequences of TCS have anti-tumour activity and that the anti-HIV property of TCS is due to inhibition of HIV-1 integrase $[13,14]$. JAR cells (a human choriocarcinoma line) are sensitive to TCS and are a useful model for cell biological study [12]. Studying the effect of TCS on JAR cells will help us to understand better the anti-tumour and anti-HIV mechanism of TCS. Here we show for the first time that TCS stimulates the production of ROS in JAR cells and that ROS are involved in the TCS-induced apoptosis of JAR cells. This finding might

Abbreviations used: BAPTA/AM, bis-(o-aminophenoxy)ethane- $N, N, N^{\prime}, N^{\prime}$-tetra-acetic acid tetra(acetoxymethyl) ester; $\left[\mathrm{Ca}{ }^{2+}\right]_{i}$, intracellular $\mathrm{Ca}^{2+}$ concentration; DCF, 2',7'-dichlorofluorescein; DETAPAC, diethylenetriaminepenta-acetic acid; DMPO, 5,5-dimethyl-1-pyrroline $N$-oxide; $\mathrm{H}_{2} \mathrm{DCF}$-DA, 2',7'-dichlorofluorescein diacetate; MTT, 3-(4,5-dimethylthiazol-2-yl)-2,5-diphenyl-2H-tetrazolium bromide; ROS, reactive oxygen species; SOD, superoxide dismutase; TCS, trichosanthin; Z-DEVD-FMK, benzyloxycarbonyl-Asp[OMe]-Glu-[OMe]Val-Asp[OMe]-CH ${ }_{2}$ F.

To whom correspondence should be addressed (e-mail mahui@tsinghua.edu.cn). 
provide new insight into the anti-tumour and anti-HIV mechanism of TCS.

\section{MATERIALS AND METHODS}

\section{Materials}

TCS was purified from tubers of T. kirilowii. RMPI 1640 and newborn calf serum were purchased from Gibco BRL (Grand Island, NY, U.S.A.). Trypsin and EDTA were products of Serva (Heidelberg, Germany). 3-(4,5-Dimethylthiazol-2-yl)-2,5diphenyl-2 $H$-tetrazolium bromide (MTT), diethylenetriaminepenta-acetic acid (DETAPAC), EGTA and mannitol were products of Sigma (St Louis, MO, U.S.A.). 2',7'-Dichlorofluorescein diacetate $\left(\mathrm{H}_{2} \mathrm{DCF}-\mathrm{DA}\right)$, fluo-3 acetoxymethyl ester, propidium iodide and Hoechst 33342 were products of Molecular Probes (Eugene, OR, U.S.A.). Trolox (6-hydroxy-2,5,7,8tetramethylchroman-2-carboxylic acid) was purchased from Aldrich Chemical Co. (Milwaukee, WI, U.S.A.). The caspase-3 colorimetric kit was a product of Clontech (Palo Alto, CA, U.S.A.). Bis-(o-aminophenoxy)ethane- $N, N, N^{\prime}, N^{\prime}$-tetra-acetic acid tetra(acetoxymethyl) ester (BAPTA/AM), catalase and superoxide dismutase (SOD) were purchased from Alexis (San Diego, CA, U.S.A.).

\section{Cell culture}

JAR cells were cultured in RMPI 1640 supplemented with $10 \%$ $(\mathrm{v} / \mathrm{v})$ heat-inactivated newborn calf serum, $100 \mathrm{i} . \mathrm{u} . / \mathrm{ml}$ penicillin and $100 \mathrm{i} . \mathrm{u} . / \mathrm{ml}$ streptomycin in a humidified air $/ \mathrm{CO}_{2}(19: 1)$ atmosphere.

\section{Measurement of ROS by confocal laser scanning microscopy}

Cells were loaded with $20 \mu \mathrm{M} \mathrm{H}_{2}$ DCF-DA in a Hepes-buffered salt solution (HBSS) supplemented with $5 \mathrm{mg} / \mathrm{ml} \mathrm{BSA} \mathrm{for} 15 \mathrm{~min}$ at $37^{\circ} \mathrm{C}$. After being rinsed twice with HBSS, cells were imaged with a Bio-Rad MRC 1024MP laser scanning confocal microscope, with excitation at $488 \mathrm{~nm}$ and emission at $510 \mathrm{~nm}$.

We typically recorded fluorescence from one field of cells per coverslip under different experiment conditions. After acquiring the images of baseline fluorescence levels, $50 \mu \mathrm{g} / \mathrm{ml}$ TCS was applied and six additional images were obtained every 5 min.

\section{ESR experiments}

Direct evidence of free radical generation in JAR cells during TCS treatment was provided by ESR spectrometry coupled to spin trapping with the nitrone 5,5-dimethyl-1-pyrroline $N$-oxide (DMPO). Cells $\left(5 \times 10^{6}\right)$ were harvested by mild treatment with trypsin, resuspended in Hanks balanced salt solution containing $0.1 \mathrm{M}$ DETAPAC and incubated with $50 \mu \mathrm{g} / \mathrm{ml} \mathrm{TCS}$ at $37^{\circ} \mathrm{C}$ for the indicated durations. Then $0.1 \mathrm{M}$ of the spin trap DMPO (purified with active charcoal before use) was added to cells, transferred into a quartz ESR sample capillary and immediately fitted into the cavity of a Bruker 200 ESR spectrometer. The temperature of the cavity was set at $37^{\circ} \mathrm{C}$. The ESR spectra were recorded exactly $2 \mathrm{~min}$ after the addition of DMPO. To measure the decay of the spin adduct, ESR spectra of the same sample were recorded $10 \mathrm{~min}$ later. To prevent any possible photochemical decomposition of the spin adduct, the ESR measurement was performed in the dark. To characterize the ESR spectra of JAR cells, an authentic spectrum of DMPO-OOH spin adduct was obtained by illuminated riboflavin, and an authentic spectrum of DMPO-OH spin adduct was obtained by the Fenton reaction. The instrument settings were: $\mathrm{X}$-band with a $100 \mathrm{kHz}$ modulation frequency and a $1 \mathrm{G}$ modulation amplitude, central magnetic field $325 \mathrm{mT}$, microwave power $10 \mathrm{~mW}$, sweep width $20 \mathrm{mT}$, time constant $0.128 \mathrm{~s}$.

\section{Observation of changes in intracellular $\mathrm{Ca}^{2+}$ concentration $\left(\left[\mathrm{Ca}^{2+}\right]_{\mathrm{i}}\right)$ with laser scanning confocal microscopy}

After treatment with $50 \mu \mathrm{g} / \mathrm{ml}$ TCS for $24 \mathrm{~h}$, cells were loaded with $5 \mu \mathrm{M}$ fluo $3 / \mathrm{AM}$ in RMPI 1640 for $1 \mathrm{~h}$ at $37^{\circ} \mathrm{C}$. After being rinsed twice with HBSS, cells were imaged by laser scanning confocal microscopy, with excitation at $488 \mathrm{~nm}$ and emission at $525 \mathrm{~nm}$.

For measurement of $\left[\mathrm{Ca}^{2+}\right]_{\mathrm{i}}$ after treatment with TCS, cells were preloaded with $5 \mu \mathrm{M}$ fluo 3/AM in RMPI 1640 for $1 \mathrm{~h}$ at $37^{\circ} \mathrm{C}$. After being washed three times with HBSS, cells were treated with $50 \mu \mathrm{g} / \mathrm{ml} \mathrm{TCS}$ and images of $\left[\mathrm{Ca}^{2+}\right]_{\mathrm{i}}$ were recorded every $20 \mathrm{~s}$ for up to $10 \mathrm{~min}$ by laser scanning confocal microscopy, with excitation at $488 \mathrm{~nm}$ and emission at $525 \mathrm{~nm}$.

\section{Observation of nuclear morphological changes by two-photon laser scanning microscopy}

After treatment with $50 \mu \mathrm{g} / \mathrm{ml}$ TCS for $24 \mathrm{~h}$, cells were loaded with $10 \mu \mathrm{g} / \mathrm{ml}$ Hoechst 33342 in RMPI 1640 for 20 min at $37^{\circ} \mathrm{C}$. After being rinsed twice with HBSS, cells were imaged with a Bio-Rad MRC 1024MP two-photon laser scanning microscope, with excitation at $730 \mathrm{~nm}$ and emission at more than $460 \mathrm{~nm}$ with the use of a long-pass emission filter.

In this study, JAR cells were double-labelled with Hoechst 33342 and $\mathrm{H}_{2}$ DCF-DA and were used for the simultaneous measurement of nuclear morphological changes by two-photon laser scanning microscopy and ROS formation by confocal laser scanning microscopy. In another experiment, JAR cells were double-labelled with Hoechst 33342 and fluo 3/AM, and were used for the simultaneous measurement of nuclear morphological changes by two-photon laser scanning microscopy and $\left[\mathrm{Ca}^{2+}\right]_{\mathrm{i}}$ changes by confocal laser scanning microscopy.

\section{MTT assay}

An MTT assay was employed to assess the viable cell number quantitatively. In brief, $100 \mu \mathrm{l}$ of cell suspension $\left(10^{4}\right.$ cells) was seeded into wells of 96-well tissue-culture plates containing the indicated concentrations of TCS. Control cells were not treated with TCS. After treatment with TCS at various concentrations for the indicated periods, MTT $(5 \mathrm{mg} / \mathrm{ml}$ final concentration) was added to each well; after incubation for $4 \mathrm{~h}$, the formazan crystals produced by viable cells were dissolved for $12 \mathrm{~h}$ with $100 \mu \mathrm{l}$ of $10 \%$ (w/v) SDS. The absorbance at $540 \mathrm{~nm}$ was measured. The viable cell number was expressed as a percentage of control cells, measured as $100 A_{540, \text { TCS-treated }} / A_{540, \text { control }}$.

\section{Flow cytometry analysis}

TCS-treated cells $\left(10^{6}\right)$ were freshly harvested, resuspended in PBS and then stained with $1 \mathrm{ml}$ of PBS containing $50 \mu \mathrm{g} / \mathrm{ml}$ propidium iodide, 100 units $/ \mathrm{ml} \mathrm{RNase}$ and $10 \mu \mathrm{l} / \mathrm{ml}$ Triton $\mathrm{X}$ 100 for at least $15 \mathrm{~min}$ at room temperature. Cells treated with $10 \mu \mathrm{g} / \mathrm{ml}$ camptothecin for $6 \mathrm{~h}$ were also examined as a positive control. Propidium iodide was detected on an EPICS ELITE Coulter counter, with excitation at $488 \mathrm{~nm}$ and emission at $620 \mathrm{~nm}$. According to the DNA content, an apoptotic percentage was given after analysis with ELITE 4.5 software. 


\section{Quantitative analysis of caspase-3 activity}

Cells $\left(2 \times 10^{6}\right)$ treated with $25 \mu \mathrm{g} / \mathrm{ml}$ TCS and $10 \mu \mathrm{g} / \mathrm{ml}$ camptothecin for indicated periods were collected and incubated for $10 \mathrm{~min}$ with chilled lysis buffer on ice. The lysate was centrifuged at $12000 \mathrm{~g}$ for $3 \mathrm{~min}$. The supernatants were transferred to a new Eppendorf tube, then $p$-nitroanilide-conjugated substrate was added. Detection of caspase-3 activity was performed at $405 \mathrm{~nm}$ on a spectrophotometer after $1 \mathrm{~h}$ of incubation at $37^{\circ} \mathrm{C}$. Protease units were quantified by comparison with a $p$-nitroanilide calibration curve: units of caspase- $3=(\Delta A / \mathrm{h}) \times(1 /$ slope of curve $)$.

\section{RESULTS}

\section{TCS induces apoptosis in JAR cells}

MTT assay was used to evaluate the cytotoxic effect of TCS on JAR cells. Figure 1(A) shows that the viable cell number decreased with treatment time, suggesting that TCS induced cell death in a time-dependent manner. Figure 1(B) shows that the viable cell number decreased as TCS concentration increased, suggesting that TCS induced cell death in a concentrationdependent manner. Statistical analysis indicated that the $\mathrm{IC}_{50}$ for $48 \mathrm{~h}$ was $25 \mu \mathrm{g} / \mathrm{ml}$. These results indicate that the cytotoxic effect of TCS on JAR cells was dependent on both time and concentration.

Cells die after either necrosis or apoptosis. Apoptosis is distinguished from necrosis by characteristic morphological and biochemical changes, including compaction and fragmentation of the chromatin, the activation of certain proteases and nucleases and the appearance of cells at sub- $\mathrm{G}_{0} / \mathrm{G}_{1}$ (the sub-diploid peak) $[1,2]$. Morphological observation of TCS-treated cells by twophoton laser scanning microscopy displayed marked chromatin condensation and apoptotic body formation (Figure 2A), demonstrating that TCS induces apoptosis in JAR cells. Flow cytometry analysis revealed the hallmark features of apoptosis, with the appearance of sub-diploid DNA (the accumulation of cells at sub- $\mathrm{G}_{0} / \mathrm{G}_{1}$ ) (Figure $2 \mathrm{~B}$ ). The sub-diploid peak began to appear in the DNA content distribution after treatment with TCS for $12 \mathrm{~h}$ and increased with treatment time. Quantitative analysis revealed that TCS induced the apoptosis of JAR cells in a time-dependent manner (Figure 2C).

\section{TCS induces production of ROS in JAR cells}

TCS-induced production of ROS was monitored at the level of single cells by using the fluorescent probe $\mathrm{H}_{2}$ DCF-DA with
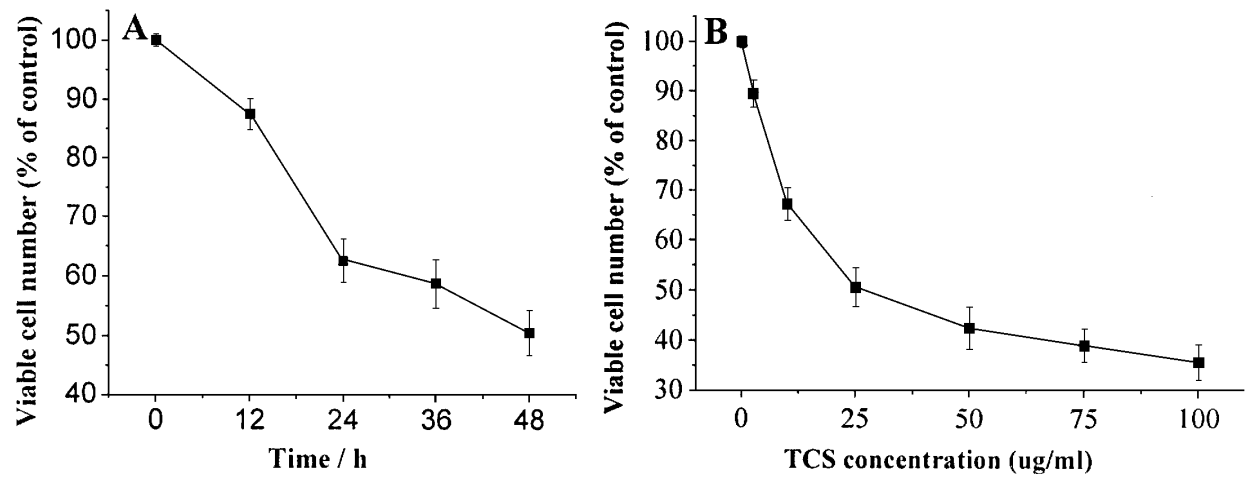

\section{Figure 1 Cytotoxic effect of TCS on JAR cells}

(A) JAR cells were treated with $25 \mu \mathrm{g} / \mathrm{ml} \mathrm{TCS}$ for the indicated periods. Control cells were not treated with TCS. (B) JAR cells were treated with the indicated concentrations of TCS for 48 h; $\mathrm{IC}_{50}$ was found to be $25 \mu \mathrm{g} / \mathrm{ml}$. The viable cell number was determined by MTT assay as described in the Materials and methods section. Results are expressed as percentages of control values (without TCS treatment) and are means \pm S.E.M. $(n=5)$. Abbreviation: ug, $\mu \mathrm{g}$.
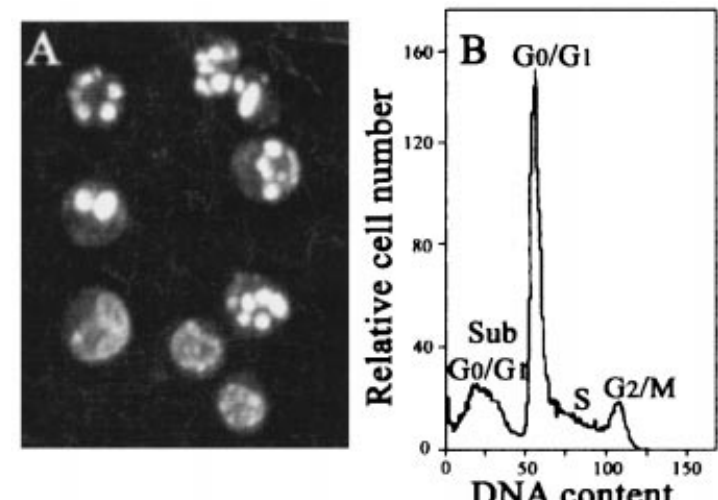

DNA content

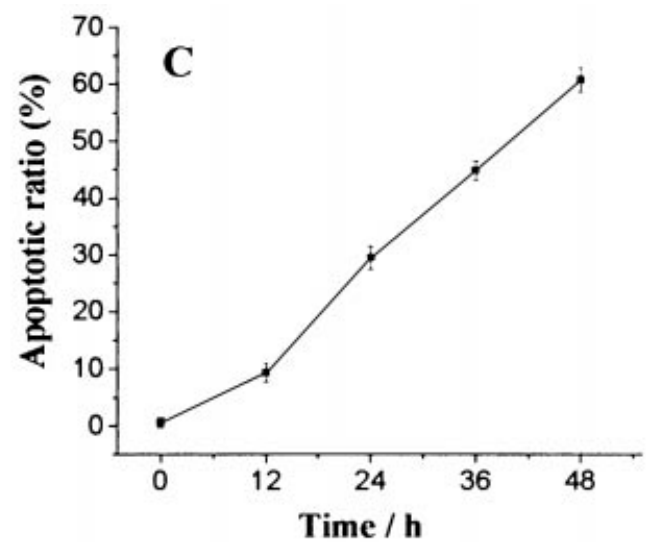

Figure 2 TCS induces apoptosis in JAR cells

(A) DNA condensation and fragmentation; (B) appearance of cells at sub- $G_{0} / G_{1} ;(\mathbf{C})$ flow cytometry analysis, showing that TCS induced apoptosis in JAR cells in a time-dependent manner 

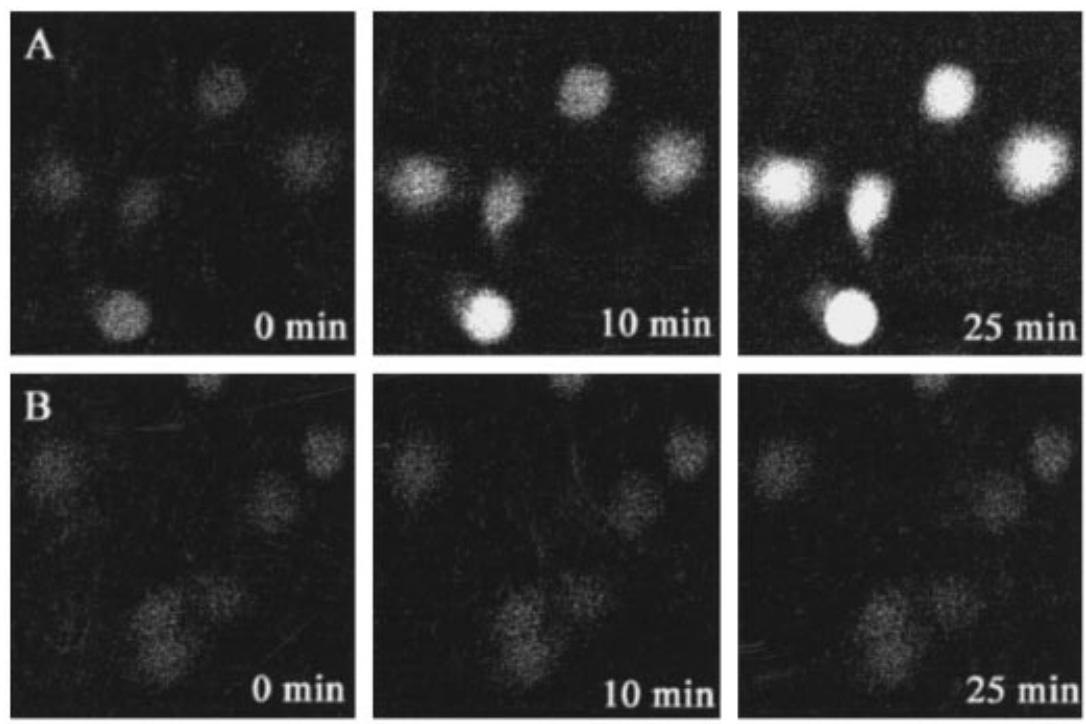

\section{Figure 3 TCS-induced ROS formation in JAR cells observed by confocal laser scanning microscopy}

(A) Cells treated with TCS $(50 \mu \mathrm{g} / \mathrm{ml})$; (B) control cells without TCS treatment. Times after the addition of TCS are shown; images were obtained every 5 min. The experiments were performed on at least 20 other coverslips, with similar results.

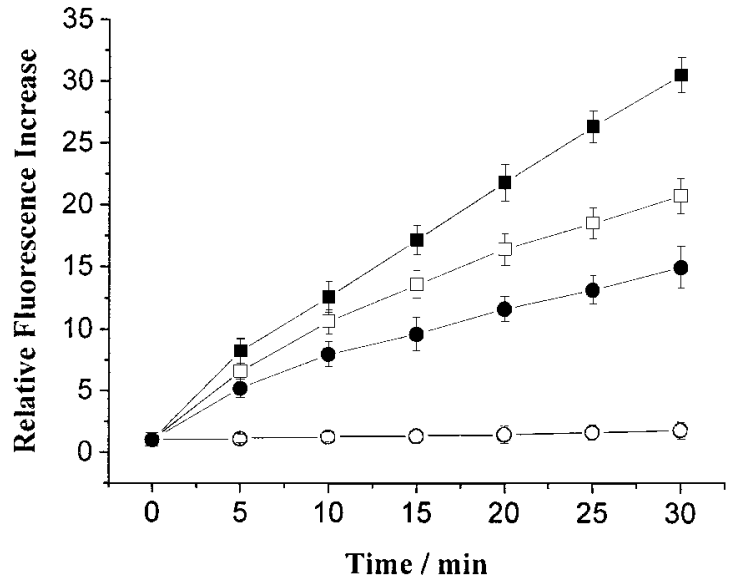

Figure 4 TCS induces the time- and concentration-dependent production of ROS in JAR cells

Symbols: JAR cells treated with $50 \mu \mathrm{g} / \mathrm{ml}(\mathbf{\square}), 25 \mu \mathrm{g} / \mathrm{ml}(\square), 15 \mu \mathrm{g} / \mathrm{ml}(\mathbf{O})$ and $0 \mu \mathrm{g} / \mathrm{ml}$ (control, O) TCS in $\mathrm{Ca}^{2+}$-containing HBSS. ROS production in single cells is expressed as the increase in fluorescence relative to the starting fluorescence. Results are means \pm S.E.M. for at least 80 cells in each condition; error bars smaller than the symbols are not shown.

confocal laser scanning microscopy. $\mathrm{H}_{2}$ DCF-DA was not sensitive to oxidizing agents; when $\mathrm{H}_{2}$ DCF-DA was added to cells, it diffused across the cell membrane and hydrolysed by intracellular esterases to $\mathrm{H}_{2} \mathrm{DCF}$. On oxidation, $\mathrm{H}_{2} \mathrm{DCF}$ yields the highly fluorescent $2^{\prime}, 7^{\prime}$-dichlorofluorescein (DCF) [19]. Figure 3 shows that exposure to $50 \mu \mathrm{g} / \mathrm{ml}$ TCS increased DCF fluorescence in all cells examined. The DCF fluorescence increased greatly over time after the application of TCS and was dispersed evenly over most of the cell body. In control experiments, in which $\mathrm{H}_{2}$ DCF-DA was loaded without TCS addition, DCF fluorescence underwent no great change. Quantitative analysis revealed that DCF fluorescence increased rapidly in response to TCS activation, and ROS production increased with both treatment time and TCS concentration (Figure 4). These results indicate that TCS stimulated the production of ROS in a time- and concentration-dependent manner.

To ascertain TCS-induced ROS in JAR cells, the spin trapping technique, which provides direct evidence of free radical generation in cells, was used for the detection of ROS. On exposure of JAR cells for $10 \mathrm{~min}$ to $50 \mu \mathrm{g} / \mathrm{ml} \mathrm{TCS}$, an ESR spectrum characteristic of DMPO-OOH spin adducts was observed (Figure 5B). The hyperfine parameters of the spectrum were: $a^{\mathrm{N}}=$ $14.3 \mathrm{G}, a_{\beta}^{\mathrm{H}}=11.7 \mathrm{G}, a_{\gamma}^{\mathrm{H}}=1.3 \mathrm{G}, g=2.0055$, which was the same as in the spectrum obtained from authentic $\mathrm{O}_{2}^{-\cdot}$ generated by illuminated riboflavin (Figure $5 \mathrm{~F}$ ). In JAR cells exposed to $50 \mu \mathrm{g} / \mathrm{ml} \mathrm{TCS}$ for $25 \mathrm{~min}$, the ESR spectrum of DMPO-OOH was strong (Figure 5D), suggesting that treatment with TCS stimulated the time-dependent generation of $\mathrm{O}_{2}^{-\cdot}$. The spin adduct DMPO-OOH was not stable and decomposed gradually into DMPO-OH. After $10 \mathrm{~min}$, the ESR spectrum of TCStreated cells showed typical characteristics of a DMPO-OH spin adduct $\left(a^{\mathrm{N}}=a^{\mathrm{H}}=14.9 \mathrm{G}, g=2.0053\right)$ (compare Figures $5 \mathrm{C}$ and $5 \mathrm{~B}$, and $5 \mathrm{D}$ and $5 \mathrm{E}$ respectively; the spectrum of authentic $\mathrm{OH}^{\cdot}$ generated by Fenton reactions is shown in Figure 5G). These results demonstrated that TCS induced the production of $\mathrm{O}_{2}^{-\cdot}$ in JAR cells in a time-dependent manner.

ROS are a family of oxygen-centred species including $\mathrm{O}_{2}^{-\cdot}$, $\mathrm{OH}^{\bullet}$ and $\mathrm{H}_{2} \mathrm{O}_{2}$. To characterize the possible ROS induced by TCS, a set of ROS scavengers, namely SOD, catalase and mannitol, were used to study their inhibitory effect on TCSinduced ROS formation (Figure 6). The $\mathrm{O}_{2}^{-\bullet}$ scavenger SOD partly suppressed TCS-induced ROS formation, corroborating the involvement of $\mathrm{O}_{2}{ }^{-\cdot}$. SOD plus the $\mathrm{H}_{2} \mathrm{O}_{2}$ scavenger catalase attenuated TCS-induced ROS in comparison with SOD, suggesting the involvement of $\mathrm{H}_{2} \mathrm{O}_{2}$. The combination of SOD plus catalase and the $\mathrm{OH}^{*}$ scavenger mannitol further attenuated TCS-induced ROS in comparison with SOD plus catalase, suggesting the involvement of $\mathrm{OH}^{\circ}$. These results 


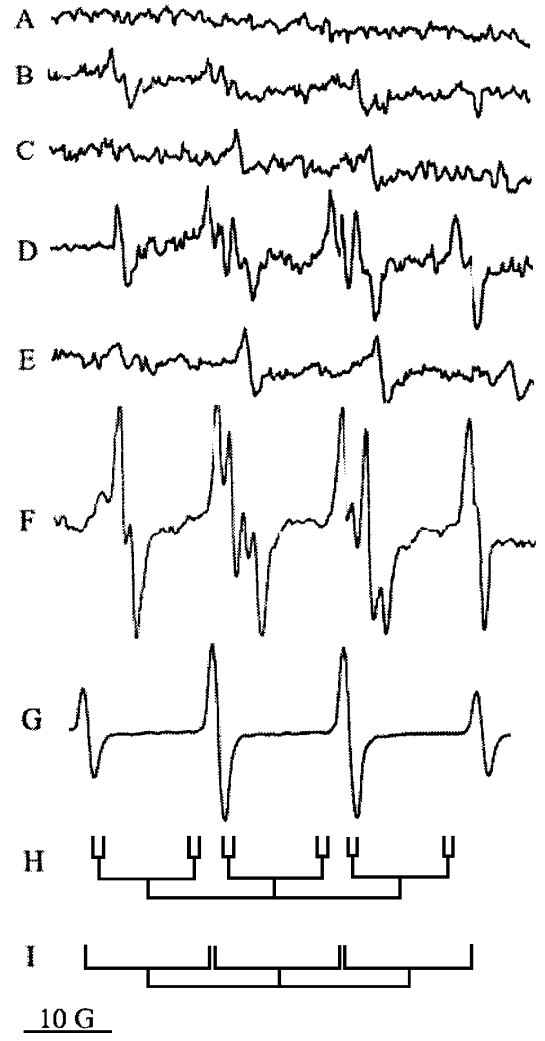

Figure 5 ESR spectra of ROS in JAR cells on exposure to TCS

(A) Control cells; (B) JAR cells treated with $50 \mu \mathrm{g} / \mathrm{ml}$ TCS for $10 \mathrm{~min}$ and then incubated with DMPO for $2 \mathrm{~min}$; (C) as in (B) except that the spectrum was recorded 10 min later; (D) JAR cells treated with TCS for 25 min then incubated with DMPO for 2 min; (E) as in (D) except that the spectrum was recorded 10 min later; (F) authentic spectrum of DMPO-OOH spin adduct; (G) authentic spectrum of DMPO-OH spin adduct; $(\mathbf{H})$ hyperfine split of the spectrum of DMPO-OOH spin adduct; (I) hyperfine split of the spectrum of DMPO-OH spin adduct. All ESR spectra were recorded at $37^{\circ} \mathrm{C}$ with the following measurement conditions: $X$-band, central magnetic field $325 \mathrm{mT}$, sweep width $20 \mathrm{mT}$, microwave power $20 \mathrm{~mW}, 100 \mathrm{kHz}$ modulation with amplitude $0.1 \mathrm{mT}$ (DMPO as spin trap) or $0.2 \mathrm{mT}$ (POBN as spin trap), time constant $0.128 \mathrm{~s}$.

demonstrate the involvement of $\mathrm{O}_{2}^{-}, \mathrm{H}_{2} \mathrm{O}_{2}$ and $\mathrm{OH}^{\cdot}$ in TCSinduced ROS. The antioxidant Trolox completely suppressed TCS-induced ROS formation (Figure 6); the highly inhibitory effect of Trolox on TCS-induced ROS formation might be related to its being a small hydrophilic molecule with closer access to the site of ROS production.

\section{TCS-induced ROS are $\mathrm{Ca}^{2+}$-dependent}

To study a possible relationship between ROS production and TCS-induced intracellular $\mathrm{Ca}^{2+}$ mobilization, we performed a set of experiments to determine the dependence of ROS on intracellular and extracellular $\mathrm{Ca}^{2+}$. Figure 7 shows that the removal of extracellular $\mathrm{Ca}^{2+}$ (Ca-containing HBSS was replaced by $\mathrm{Ca}-$ free HBSS) blocked the increase in DCF fluorescence induced by TCS. This result indicates that TCS-induced ROS in JAR cells was dependent on $\mathrm{Ca}^{2+}$. Pretreatment with BAPTA/AM, which penetrated into the cells and hydrolysed by intracellular esterases to the intracellular $\mathrm{Ca}^{2+}$ chelator BAPTA, TCS-induced levels of ROS were further decreased in comparison with those in Ca-free HBSS without BAPTA/AM treatment (Figure 7). This result

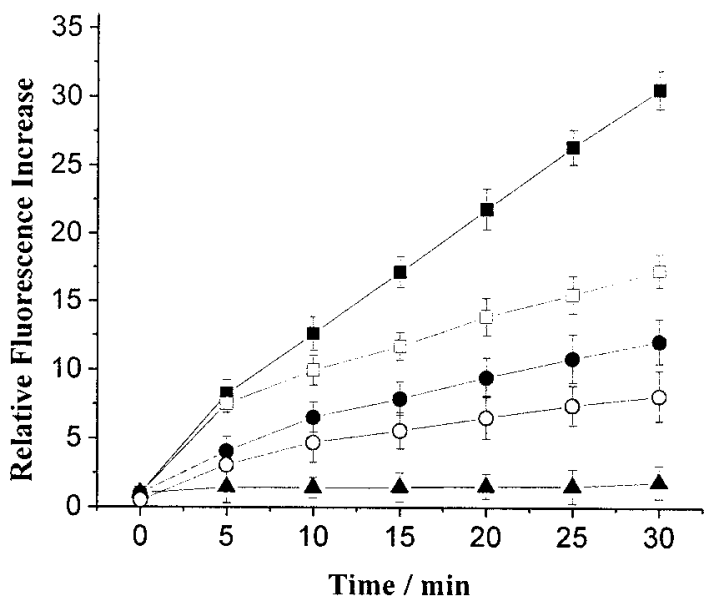

Figure 6 Inhibitory effects of ROS scavengers and the antioxidant Trolox on TCS-induced ROS formation

Symbols: $\square$, JAR cells treated with $50 \mu \mathrm{g} / \mathrm{ml}$ TCS in Ca-containing HBSS; $\square$, JAR cells pretreated with 500 units $/ \mathrm{ml} \mathrm{SOD}$ for $15 \mathrm{~min}$, followed by the addition of $50 \mu \mathrm{g} / \mathrm{ml}$ TCS; JAR cells pretreated with 500 units $/ \mathrm{ml} \mathrm{SOD}$ and 500 units/ml catalase for $15 \mathrm{~min}$, followed by the addition of $50 \mu \mathrm{g} / \mathrm{ml}$ TCS; O, JAR cells pretreated with 500 units $/ \mathrm{ml} \mathrm{SOD,} 500$ units $/ \mathrm{ml}$ catalase and $10 \mathrm{mM}$ mannitol for $15 \mathrm{~min}$, followed by the addition of $50 \mu \mathrm{g} / \mathrm{ml}$ TCS; $\boldsymbol{\Delta}$, JAR cells pretreated with $50 \mu \mathrm{M}$ Trolox for $15 \mathrm{~min}$, followed by the addition of $50 \mu \mathrm{g} / \mathrm{ml}$ TCS. ROS production in single cells is expressed as the increase in fluorescence relative to the starting fluorescence. Results are means \pm S.E.M. for at least 80 cells in each condition; error bars smaller than the symbols are not shown.

further indicates that TCS-induced ROS were $\mathrm{Ca}^{2+}$-dependent. We also investigated the effect of TCS on $\left[\mathrm{Ca}^{2+}\right]_{i}$. Figure 8 shows that TCS rapidly increased $\left[\mathrm{Ca}^{2+}\right]_{\mathrm{i}}$ over the treatment time. We found that ROS production was in accordance with the $\left[\mathrm{Ca}^{2+}\right]_{\mathrm{i}}$ elevation induced by TCS (compare Figures 4 and 8 ). It therefore seemed possible that ROS production in TCS-treated JAR cells might be a consequence of $\mathrm{Ca}^{2+}$ signalling.

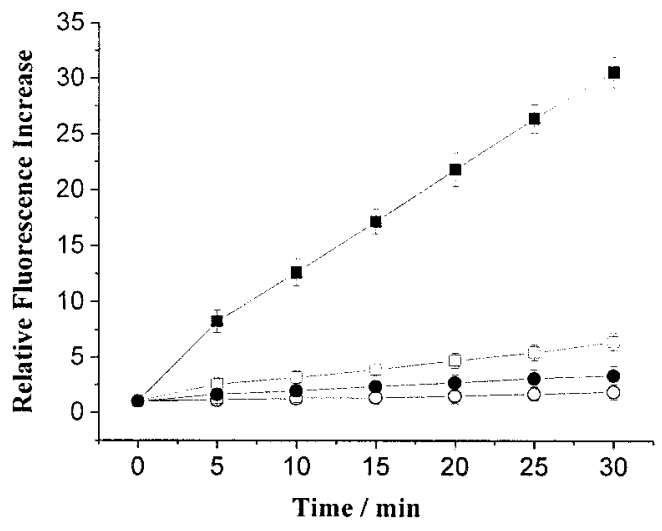

Figure 7 Dependence of TCS-induced ROS on the presence of both extracellular and intracellular $\mathrm{Ca}^{2+}$

Symbols: $\square$, TCS-treated JAR cells in Ca-containing HBSS; $\square$, TCS-treated JAR cells in Cafree HBSS; - JAR cells pretreated with $20 \mu \mathrm{M}$ BAPTA/AM in Ca-free HBSS, followed by the addition of $50 \mu \mathrm{g} / \mathrm{ml}$ TCS; $O$, control JAR cells without TCS added in Ca-containing HBSS. ROS production in single cells is expressed as the increase in fluorescence relative to the starting fluorescence. Results are means \pm S.E.M. for at least 80 cells in each condition; error bars smaller than the symbols are not shown. 


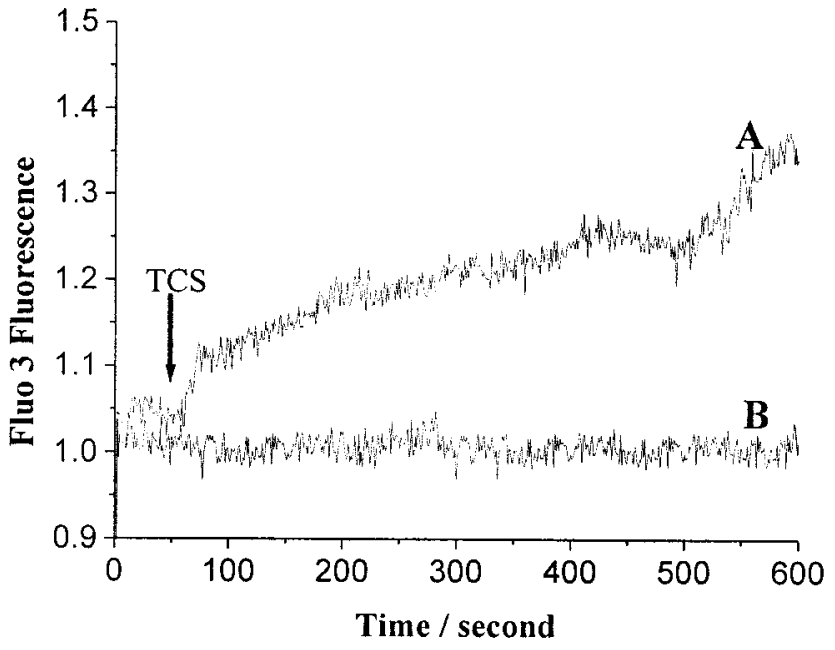

Figure 8 Changes in $\left[\mathrm{Ca}^{2+}\right]_{\mathrm{i}}$ in JAR cells after treatment with $50 \mu \mathrm{g} / \mathrm{ml} \mathrm{TCS}$ (trace A) and without TCS treatment (trace B; control)

Cells were pretreated with $5 \mu \mathrm{M}$ fluo 3/AM in RMPI 1640 for $1 \mathrm{~h}$. After three washes in HBSS, cells were treated with $50 \mu \mathrm{g} / \mathrm{ml}$ TCS in Ca-containing HBSS. With confocal microscopy, images of $\left[\mathrm{Ca}^{2+}\right]_{i}$ were recorded every $10 \mathrm{~s}$ for up to $10 \mathrm{~min}$. $\left[\mathrm{Ca}^{2+}\right]_{\mathrm{i}}$ is expressed as the emission intensity of fluo 3 at $525 \mathrm{~nm}$. Results were recorded for a representative single cell and are presented as multiples of the fluorescence at zero time.
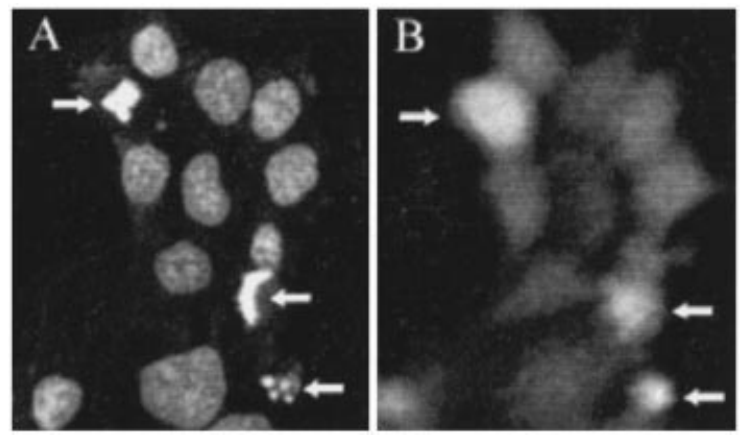

Figure 9 Nuclear morphological changes and ROS production in JAR cells after treatment with $50 \mu \mathrm{g} / \mathrm{ml}$ TCS for $24 \mathrm{~h}$

JAR cells were double-loaded with Hoechst 33342 and $\mathrm{H}_{2}$ DCF-DA, as described in the Materials and methods section. Images of Hoechst 33342 fluorescence $(\mathbf{A})$ and DCF fluorescence (B) were collected simultaneously by two-photon laser scanning microscopy and confocal laser scanning microscopy. Apoptotic cells (arrow) showed chromatin condensation and apoptotic body formation (A) and high production of ROS (B).

\section{Involvement of ROS in TCS-induced apoptosis of JAR cells}

Accumulating evidence indicates that ROS are second messengers in the activation of enzymes and transcription factors and in growth, differentiation and apoptosis [6-9]. To assess whether ROS are involved in the TCS-induced apoptosis of JAR cells, we simultaneously observed nuclear morphological changes by twophoton laser scanning microscopy and ROS production in JAR cells by confocal laser scanning microscopy. Figure 9 shows that ROS production increased in the apoptotic cells with chromatin condensation and apoptotic body formation, indicating that ROS are involved in the TCS-induced apoptosis of JAR cells.

The involvement of ROS in TCS-induced apoptosis was also confirmed by the inhibition of TCS-induced cell death by Trolox

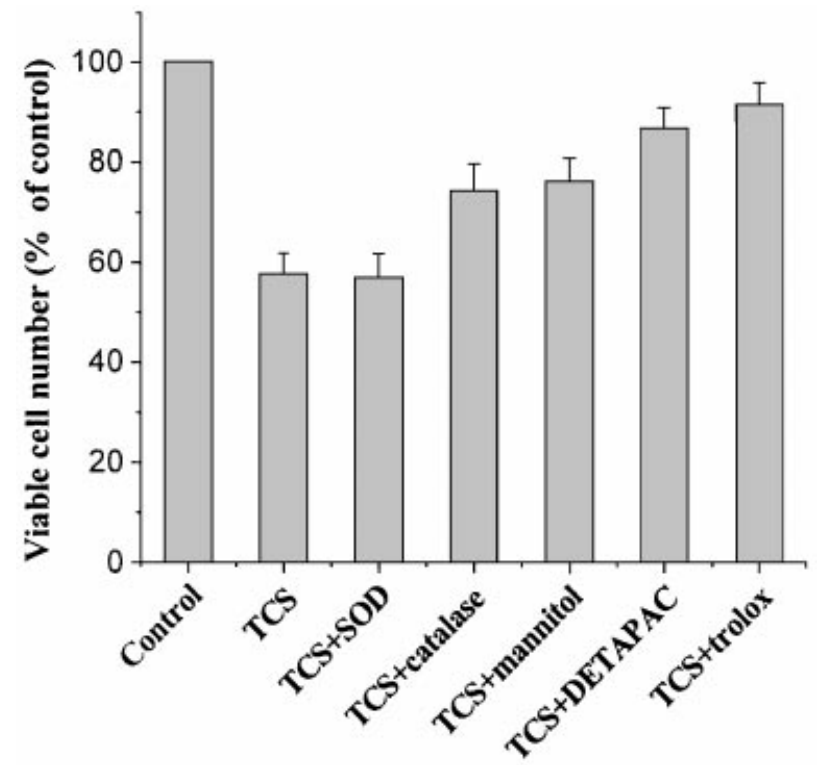

Figure 10 Inhibitory effects of ROS scavengers (catalase and mannitol), the metal chelator DETAPAC and the antioxidant Trolox on TCS-induced cell death

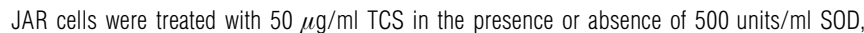
500 units/ml catalase, $10 \mathrm{mM}$ mannitol, $100 \mu \mathrm{M}$ DETAPAC or $50 \mu \mathrm{M}$ Trolox for $24 \mathrm{~h}$. Viable cell number was determined by MTT assay as described in the Materials and methods section. Results are expressed as percentages of control (without TCS) and are means \pm S.E.M. $(n=8)$.

and the ROS scavengers catalase and mannitol (Figure 10). The MTT assay revealed that the antioxidant Trolox, the $\mathrm{H}_{2} \mathrm{O}_{2}$ scavenger catalase and the $\mathrm{OH}^{*}$ scavenger mannitol could effectively suppress TCS-induced cell death; however, SOD had no significant inhibitory effect on TCS-induced cell death; this might have resulted from the enhanced formation of $\mathrm{OH}^{*}$, probably the most potent of the ROS. SOD catalyses the conversion of $\mathrm{O}_{2}^{-\bullet}$ to $\mathrm{H}_{2} \mathrm{O}_{2}$, and $\mathrm{OH}^{\cdot}$ can be produced from both $\mathrm{O}_{2}^{-\cdot}$ and $\mathrm{H}_{2} \mathrm{O}_{2}$ via either the Fenton reaction or the Haber-Weiss reaction:

$\mathrm{Fe}^{2+}+\mathrm{H}_{2} \mathrm{O}_{2} \rightarrow \mathrm{Fe}^{3+}+\mathrm{OH}^{\cdot}+\mathrm{OH}^{-}$(Fenton reaction)

$\mathrm{O}_{2}^{-\cdot}+\mathrm{H}_{2} \mathrm{O}_{2} \rightarrow \mathrm{O}_{2}+\mathrm{OH}^{\cdot}+\mathrm{OH}^{-}$(Haber-Weiss reaction)

DETAPAC, an inhibitor of metal-facilitated $\mathrm{OH}^{*}$ formation via the Fenton reaction, markedly inhibited TCS-induced cell death, suggesting that the $\mathrm{OH}^{*}$ responsible for TCS-induced cell death was produced by the Fenton reaction (Figure 10). The high degree of inhibition by DETAPAC and Trolox compared with that by catalase and mannitol might be a results of the small size of both DETAPAC and Trolox, which might therefore have closer access to the site of ROS production. All of the above results suggest that ROS might be the mediator of cell death and be involved in TCS-induced apoptosis.

\section{Involvement of $\mathrm{Ca}^{2+}$ in TCS-induced apoptosis of JAR cells}

It has been demonstrated that an increase in $\left[\mathrm{Ca}^{2+}\right]_{\mathrm{i}}$ is important in the induction of $\mathrm{Ca}^{2+}$-dependent endonucleases and in the initiation of apoptosis [20-22]. Simultaneous observation of nuclear morphological changes by two-photon laser scanning microscopy and $\left[\mathrm{Ca}^{2+}\right]_{\mathrm{i}}$ changes by confocal laser scanning microscopy revealed a high fluo-3 fluorescence of the apoptotic 

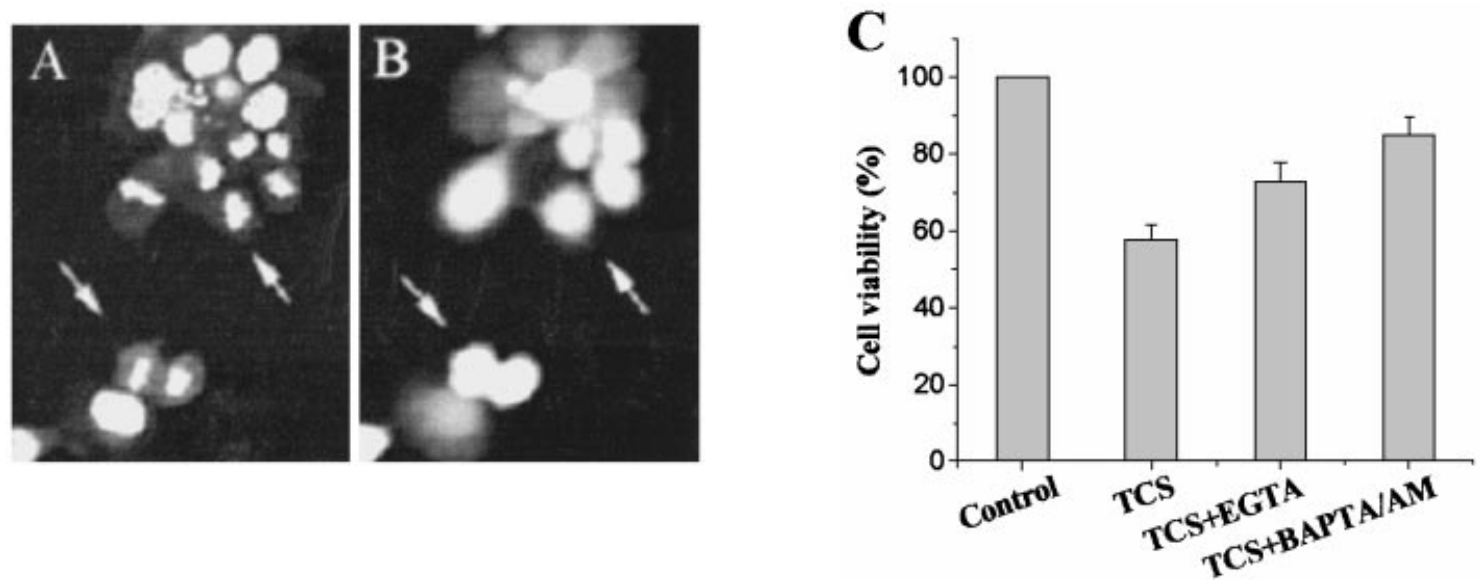

\section{Figure 11 Involvement of $\mathrm{Ca}^{2+}$ in TCS-induced apoptosis of JAR cells}

(A, B) Simultaneous observation of nuclear morphological changes and intracellular $\mathrm{Ca}^{2+}$ changes in JAR cells after treatment with $50 \mu \mathrm{g} / \mathrm{ml}$ TCS for $24 \mathrm{~h}$. JAR cells were double-loaded with Hoechst 33342 and fluo 3/AM as described in the Materials and methods section. Images of Hoechst 33342 fluorescence (A) and fluo 3 fluorescence (B) were collected simultaneously by twophoton laser scanning microscopy and confocal laser scanning microscopy. Apoptotic cells (arrow) showed chromatin condensation and apoptotic body formation $(\mathbf{A})$ and high $\left[\mathrm{Ca}^{2+}\right]_{\mathrm{i}}(\mathbf{B})$. (C) Effects of $\mathrm{Ca}^{2+}$ chelators on TCS-induced cell death. JAR cells were treated for $24 \mathrm{~h}$ with $50 \mu \mathrm{g} / \mathrm{ml}$ TCS in the presence or absence of $20 \mu \mathrm{M}$ BAPTA/AM or $1 \mathrm{mM}$ EGTA. Viable cell number was determined by MTT assay as described in the Materials and methods section. Results are expressed as percentages of control (without TCS) and are represented as means \pm S.E.M. ( $n=6$ ).
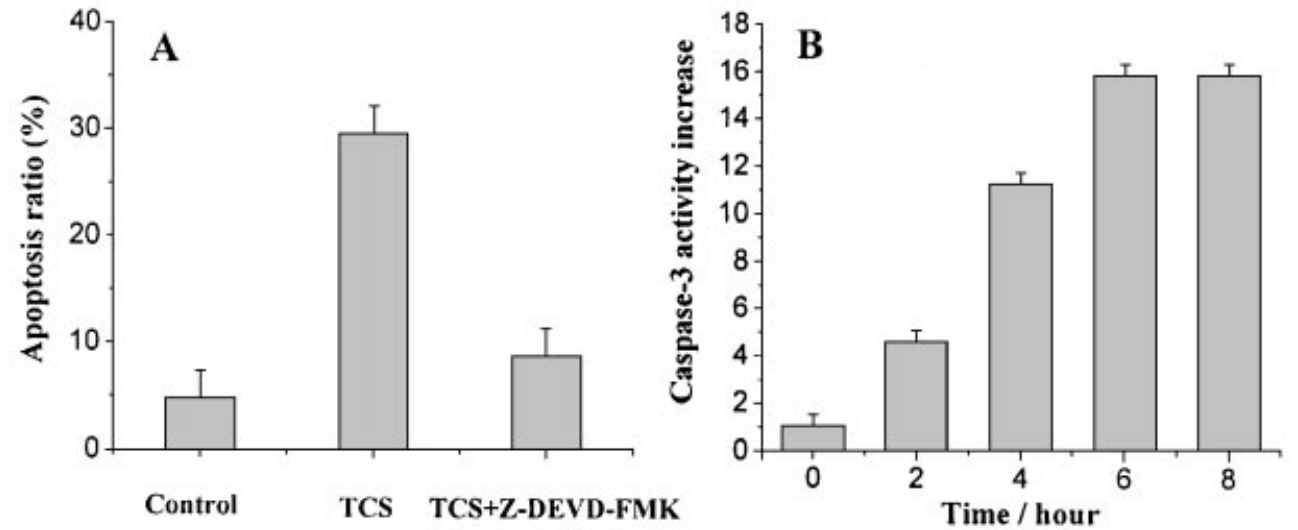

\section{Figure 12 Involvement of caspase-3 in TCS-induced apoptosis of JAR cells}

(A) Inhibition of TCS-induced apoptosis by Z-DEVD-FMK. Cells were preincubated for $1 \mathrm{~h}$ with $100 \mu \mathrm{M}$ Z-DEVD-FMK before the addition of $25 \mu \mathrm{g} / \mathrm{ml}$ TCS. After treatment for $24 \mathrm{~h}$, the percentage of apoptotic cells was determined by flow cytometry. Results are means \pm S.E.M. for three individual experiments. (B) Activation of caspase- 3 in JAR cells induced by TCS. Cells $\left(2 \times 10^{6}\right)$ were incubated with $25 \mu \mathrm{g} / \mathrm{ml}$ TCS for the indicated periods. Caspase-3 activities were assayed as described in the Materials and methods section. Results are means \pm S.E.M. for three individual experiments.

cells after treatment with TCS for $24 \mathrm{~h}$ (Figures 11A and 11B), indicating an increase in $\left[\mathrm{Ca}^{2+}\right]_{\mathrm{i}}$ in the apoptotic cells. To ascertain the involvement of $\mathrm{Ca}^{2+}$ in the TCS-induced apoptosis of JAR cells, we also investigated the effects of the intracellular $\mathrm{Ca}^{2+}$ chelator BAPTA/AM and the extracellular $\mathrm{Ca}^{2+}$ chelator EGTA on TCS-induced cell death (Figure 11C). The results indicate that both EGTA and BAPTA/AM inhibited TCS-induced cell death, suggesting the involvement of $\mathrm{Ca}^{2+}$ in TCS-induced apoptosis of JAR cells. A comparison of Figures 9, 11(A) and 11(B) shows that the distribution of intracellular $\mathrm{Ca}^{2+}$ was in accordance with the distribution of ROS within apoptotic cells, confirming that ROS production was $\mathrm{Ca}^{2+}$ dependent and involved in the TCSinduced apoptosis of JAR cells.

\section{Involvement of caspase-3 in TCS-induced apoptosis of JAR cells}

Activated caspases degrade specific structural, regulatory and DNA-repairing proteins within the target cell and have essential roles in the onset of apoptosis [23-25]. To understand the role of caspase- 3 in TCS-induced apoptosis, we pretreated cells with the cell-permeable caspase-3 inhibitor benzyloxycarbonylAsp[OMe]-Glu-[OMe]Val-Asp[OMe]- $\mathrm{CH}_{2} \mathrm{~F}$ (Z-DEVD-FMK) before exposure to TCS. Figure 12(A) shows that TCS-induced apoptosis was significantly inhibited by pretreatment of cells with Z-DEVD-FMK, suggesting the involvement of caspase-3 in TCS-induced apoptosis. It has been reported that caspase- 3 induces the generation of $\mathrm{H}_{2} \mathrm{O}_{2}[26,27]$. To determine whether 
caspases are involved in ROS production during JAR-cell apoptosis induced by TCS, we assessed the caspase- 3 activity quantitatively with a caspase-3 colorimetric kit. Figure 12(B) shows that caspase- 3 activity was initiated within $2 \mathrm{~h}$ of TCS addition; continued to increase and reached a maximum at approx. $6 \mathrm{~h}$ after the addition of TCS. A comparison of Figures 4 and 12(B) shows that both ROS production and caspase-3 activation increased with TCS treatment duration. However, whereas the TCS-induced production of ROS was initiated within $5 \mathrm{~min}$, the activation of caspase- 3 was initiated within $2 \mathrm{~h}$, suggesting that the former preceded the latter.

\section{DISCUSSION}

TCS belongs to the type I ribosome-inactivating protein family [28] and consists of a single chain $(27 \mathrm{kDa})$ that shows sequence similarity to the A chain of many type II ribosome-inactivating proteins [29]. TCS can inactivate the ribosome by removing adenine- 4324 in $28 \mathrm{~S}$ rRNA, by N-glycosidase activity [30]. The increasing evidence to suggest that TCS has a broad spectrum of biological and pharmacological activities, including abortifacient, anti-tumour and anti-HIV activities [10-18], the proposed mechanisms of which include anti-tumour activity of the N-terminal sequences of TCS and anti-HIV action by the inhibition of HIV-1 integrase [13,14]. In this study we found for the first time that TCS-induced ROS are involved in the apoptosis of JAR cells. This finding might provide new insight into the anti-tumour and anti-HIV mechanism of TCS.

In the present study we characterized the possible ROS involved in the TCS-induced apoptosis of JAR cells by ESR and by the use of a set of ROS scavengers including SOD, catalase and mannitol. ESR studies demonstrated that TCS induced the production of $\mathrm{O}_{2}^{-}$, which is an initial oxygen radical species that can lead to secondary radicals or ROS such as $\mathrm{H}_{2} \mathrm{O}_{2}$ or $\mathrm{OH}^{\cdot}$ [31]. Both the $\mathrm{H}_{2} \mathrm{O}_{2}$ scavenger catalase and the $\mathrm{OH}^{\cdot}$ scavenger mannitol inhibited TCS-induced ROS formation and cell death, demonstrating the involvement of $\mathrm{H}_{2} \mathrm{O}_{2}$ and $\mathrm{OH}^{*}$. DETAPAC, an inhibitor of metal-facilitated $\mathrm{OH}^{*}$ formation, markedly inhibited TCS-induced cell death, suggesting that TCS induced $\mathrm{OH}^{*}$ formation via the Fenton reaction. The hydrophilic antioxidant Trolox completely suppressed TCS-induced ROS formation and cell death, further demonstrating the involvement of ROS in the TCS-induced apoptosis of JAR cells.

There are several sites of ROS production in non-phagocytic cells, including plasma membranes, mitochondria, endoplasmic reticulum and peroxisomes, each site being associated with its own set of oxidative enzymes (plasma membrane NADH oxidase, cytochrome oxidase, cytochrome $\mathrm{P} 450$, xanthine oxidase, monoamine oxidase, cyclo-oxygenases and lipoxygenases) [32]. There is increasing experimental evidence that non-phagocytic cells express a potent ligand-stimulated ROS-producing NADH oxidase that is membrane bound and produces far more ROS than xanthine oxidase and a mitochondrial source [32-34]. Recent studies have shown that TCS interacts with and enters cells via low-density-lipoprotein receptor family members and that the effect of TCS is mediated through its interaction with chemokine receptors $[35,36]$. Figures 3 and 4 show that TCS-induced ROS increase rapidly within a relatively short time of the application of TCS and that ROS are evenly dispersed over the cytoplasm, suggesting that TCS might induce the production of ROS through its interaction with a membrane-bound receptor.

The role of $\mathrm{Ca}^{2+}$ in ROS formation is complicated. $\left[\mathrm{Ca}^{2+}\right]_{\mathrm{i}}$ elevation is not necessary for ROS formation, as is demonstrated by the observation that the generation of ROS stimulated by platelet activating factor is absolutely dependent on intracellular
$\mathrm{Ca}^{2+}$ [37]; however, in a variety of cells, ROS increase $\left[\mathrm{Ca}^{2+}\right]_{\mathrm{i}}$ [38-40]. In the present study we have shown that TCS-induced ROS are dependent on the presence of both extracellular and intracellular $\mathrm{Ca}^{2+}$. The removal of extracellular $\mathrm{Ca}^{2+}$ partly suppressed TCS-induced ROS in JAR cells. When cytosolic $\mathrm{Ca}^{2+}$ was chelated by BAPTA, TCS-induced ROS were suppressed further but were still evident (Figure 7), suggesting that TCSinduced ROS were dependent on the presence of both extracellular and intracellular $\mathrm{Ca}^{2+}$ but were not absolutely dependent on the presence of $\mathrm{Ca}^{2+}$; another mechanism such as an interaction with a membrane-bound receptor might be involved in TCS-induced ROS formation in JAR cells. $\mathrm{Ca}^{2+}$ acts as a second messenger in many biological processes; changes in $\left[\mathrm{Ca}^{2+}\right]_{\mathrm{i}}$ modulate cell functions (e.g. secretion, enzyme activation and cell cycle regulation) [41,42]. In non-phagocytic cells, ROS production was associated with a set of oxidative enzymes, which were regulated by intracellular $\mathrm{Ca}^{2+}[32]$. TCS-induced $\left[\mathrm{Ca}^{2+}\right]_{\mathrm{i}}$ elevation was in accordance with ROS production, indicating that ROS production might be a consequence of $\mathrm{Ca}^{2+}$ signalling.

Great differences were observed in the role of caspase- 3 in ROS formation; it has been reported that $\mathrm{H}_{2} \mathrm{O}_{2}$ causes the activation of the intracellular death-signalling protease caspase3 [43]; conversely, several reports have indicated that caspase-3 induces the generation of $\mathrm{H}_{2} \mathrm{O}_{2}$ [26,27]. In the present study, TCS induced the activation of caspase- 3 in a time-dependent manner in JAR cells, in accordance with the production of ROS. TCSinduced production of ROS was initiated within $5 \mathrm{~min}$, whereas activation of caspase- 3 was initiated within $2 \mathrm{~h}$, suggesting that the former precedes the latter. However, it is still not understood whether or not the TCS-induced production of ROS causes the activation of caspase-3; this needs further investigation.

Various factors are known to elicit apoptosis, including hormones, toxins, chemotherapeutic drugs, carcinogens, growth factor withdrawal and physical trauma [2]. The cellular signalling events leading to apoptosis are also varied and include $\left[\mathrm{Ca}^{2+}\right]_{\mathrm{i}}$ elevation, activation of protein kinase $\mathrm{C}$ or protein kinase $\mathrm{A}$, activation of tyrosine kinase, ROS production and caspase activation. These cellular signalling events are not common intermediate and essential elements in the induction of apoptosis; several reports have indicated that apoptosis can occur in the absence of ROS production, $\left[\mathrm{Ca}^{2+}\right]_{i}$ elevation and caspase activation [44-46]. In the present study we demonstrated that TCS induces the apoptosis of JAR cells via ROS production, $\left[\mathrm{Ca}^{2+}\right]_{i}$ elevation and caspase-3 activation. It seemed possible that TCS simultaneously activates three separate but correlated pathways: mobilization of $\mathrm{Ca}^{2+}, \mathrm{Ca}^{2+}$-dependent and receptormediated generation of ROS, and caspase- 3 activation, which subsequently leads to the apoptosis of JAR cells. Garcia et al. [47] have reported the clinical and pathological features of severe multifocal necrosis in two HIV-infected patients who experienced neurological reactions to TCS; this extensive necrosis might have resulted in part from an increased formation of ROS induced by TCS. Taken together, the finding that ROS are involved in TCSinduced apoptosis of JAR cells might provide new insight into the anti-tumour and anti-HIV mechanisms of TCS.

This work was supported by the Tsinghua University Foundation for Basic Research and the Chinese Postdoctoral Foundation.

\section{REFERENCES}

1 Ellis, R. E., Yuan, J. and Horvitz, H. R. (1991) Mechanisms and functions of cell death. Annu. Rev. Cell Biol. 7, 663-698

2 Kerr, J. F. R., Winterford, C. M. and Harmon, B. V. (1994) Apoptosis - its significance in cancer and cancer therapy. Cancer 73, 2013-2026 
3 Keer, J. F. R. (1971) Shrinkage necrosis: a distinct mode of cellular death. J. Pathol. 105, 13-20

4 Dreher, D. and Junod, A. F. (1996) Role of oxygen free radicals in cancer development. Eur. J. Cancer. 32A, 30-38

5 Ames, B. N., Shigenaga, M. K. and Hagen, T. M. (1995) Mitochondrial decay in aging. Biochim. Biophys. Acta 1271, 165-170

6 Goldman, R., Moshonov, S. and Zor, U. (1998) Generation of reactive oxygen species in a human keratinocyte cell line: role of calcium. Arch. Biochem. Biophys. 350 , 10-18

7 Sen, C. K. and Packer, L. (1996) Antioxidant and redox regulation of gene transcription. FASEB J. 10, 709-720

8 Suzuki, Y. J., Forman, H. J. and Sevanian, A. (1997) Oxidants as stimulators of signal transduction. Free Radical Biol. Med. 22, 269-285

9 Finkel, T. (1998) Oxygen radicals and signaling. Curr. Opin. Cell Biol. 10, 248-253

10 Jin, Y. C. (1985) Clinical study of trichosanthin. In Advance in Chinese Medicinal Material Research (Chang, H. M., Yeung, H. W., Tso, W. W. and Koo, A., eds.), pp. 319-326, World Scientific Publishing Co., Singapore

11 Huang, Y. (1987) Treatment of malignant trophoblastic neoplasia with trichosanthin. Chin. J. Integ. Tradit. West. Med. 7, 154-155

12 Tsao, S. W., Kan, K. T. and Yeung, H. W. (1986) Selective killing of choriocarcinoma cells in vitro by trichosanthin, a plant protein purified from root tubers of the Chinese medicinal herb Trichosanthes kirilowii. Toxicon 24, 831-840

13 Takemoto, D. J. (1998) Effect of trichosanthin an anti-leukemia protein on normal mouse spleen cells. Anticancer Res. 18, 357-361

14 Au, T. K., Collins, R. A., Lam, T. L., Ng, T.B., Fong, W. P. and Wan, D. C. C. (2000) The plant ribosome inactivating luffin and saporin are potent inhibitors of HIV-1 integrase. FEBS Lett. 471, 169-172

15 McGrath, M. S., Hwang, K. M., Caldwell, S. E., Gaston, I., Luk, K. C., Wu, P., Ng, V. L., Crowe, S., Daniels, J., Marsh, J. et al. (1989) GLQ223: an inhibitor of human immunodeficiency virus replication in acutely and chronically infected cells of lymphocyte and mononuclear phagocyte lineage. Proc. Natl. Acad. Sci. U.S.A. 86, 2844-2848

16 Kahn, J. 0., Gorelick, K. J., Gatti, G., Arri, C. J., Lifson, J. D., Gambertoglio, J. G., Bostrom, A. and Williams, R. L. (1994) Safety, activity and pharmacokinetics of GLQ223 in patient with AIDS and AIDS-related complex. Antimicrob. Agents Chemother. 38, 260-267

17 Byers, V. S., Levin, A. S., Waites, L. A., Starret, B. A., Mayer, R. A., Clegg, J. A. Price, M. R., Robins, R. A., Delaney, M. and Baldwin, R. W. (1990) A phase I/II study of trichosanthin treatment of HIV disease. AIDS 4, 1189-1196

18 Kahn, J. 0., Kaplan, L. D., Gambertoglio, J. G., Bredesen, D., Arri, C. J., Turin, L., Kibort, T., Williams, R. L., Lifson, J. D. and Volberding. P. A. (1990) The safety and pharmacokinetics of GLQ223 in subjects with AIDS and AIDS-related complex: a phase I study. AIDS 4, 1197-1204

19 Zhu, H., Bannerberg, G., Moldeus, P. and Shertzer, H. (1994) Oxidation pathways for the intracellular probe $2^{\prime}, 7^{\prime}$-dichlorofluorescein. Arch. Toxicol. 68, 582-587

20 McConkey, D. J., Nicotera, P., Hartzell, P., Bellomo, G. and Wyllie, A. H. (1989) Glucocorticoids activate a suicide process in thymocytes through an elevation of cytosolic $\mathrm{Ca}^{2+}$ concentration. Arch. Biochem. Biophys. 269, 365-370

21 McConkey, D. J., Hartzell, P., Nicotera, P., Wyllie, A. H. and Orrenius, S. (1988) Stimulation of endogenous endonuclease activity in hepatocytes exposed to oxidative stress. Toxicol. Lett. 42, 123-130

22 Takahashi, S., Maecker, H. T. and Levy, R. (1989) DNA fragmentation and cell death mediated by $T$ cell antigen receptor/CD3 complex on a leukemia $T$ cell line. Eur. J. Immunol. 19, 1911-1919

23 Thornberry, N. A. and Lazebnik, Y. (1998) Caspases: enemies within. Science 281 $1312-1316$

24 Stennicke, H. R. and Salvesen, G. S. (1997) Biochemical characteristics of caspase-3, $-6,-7$, and -8. J. Biol. Chem. 272, 25719-25723

25 Kothakota, S., Azuma, T., Reinhard, C., Kippel, A., Tang, J., Chu, K., McGary, T. J., Kirschner, W. M., Koths, K., Kwiatkowski, D. J. and Williams, L. T. (1997) Caspase-3generated fragment of gelsolin: effector of morphological change in apoptosis. Science 278, 294-297

26 Simizu, S., Takada, M., Umezawa, K. and Imoto, M. (1998) Requirement of caspase3 (-like) protease-mediated hydrogen peroxide production for apoptosis induced by various anticancer drugs. J. Biol. Chem. 273, 26900-26907
27 Simizu, S., Umezawa, K., Takada, M., Arber, N. and Imoto, M. (1998) Induction of hydrogen peroxide production and Bax expression by caspase-3(-like) proteases in tyrosine kinase inhibitor-induced apoptosis in human small cell lung carcinoma cells. Exp. Cell Res. 238, 197-203

28 Li, M. X., Yeung, H. W., Pan, C. P. and Chan, S. I. (1991) Trichosanthin, a potent HIV-1 inhibitor, can cleave supercoiled DNA in vitro. Nucleic Acids Res. 19, $6309-6312$

29 Zhang, X. J. and Wang, J. H. (1986) Homology of trichosanthin and ricin A chain. Nature (London) 321, 477-478

30 Zhang, J. S. and Liu, W. Y. (1992) The mechanism of action of trichosanthin on eukaryotic ribosomes-RNA N-glycosidase activity of the cytotoxin. Nucleic Acids Res. 20, $1271-1275$

31 Pieper, G. M., Langenstroer, P. and Siebeneich, W. (1997) Diabetic-induced endothelial dysfunction in rat aort: role of hydroxyl radicals. Cardiovasc. Res. $\mathbf{3 4}$ 145-156

32 Henderson, L. M. and Chappell, J. B. (1996) NADPH oxidase of neutrophils. Biochim. Biophys. Acta 1273, 87-107

33 De Keulenaer, G. W., Alexander, R. W., Ushio-Fukai, M., Ishizaka, N. and Griending, K. K. (1998) Tumour necrosis factor $\alpha$ activates a p22 (phox)-based NADH oxidase in vascular smooth muscle. Biochem. J. 329, 653-657

34 Rajagopalan, S., Kurz, S., Munzel, T., Tarpey, M., Freeman, B. A., Griendling, K. K. and Harrison, D. G. (1996) Angiotensin II-mediated hypertension in the rat increases vascular superoxide production via membrane NADH/NADPH oxidase activation - contribution to alterations of vasomotor tone. J. Clin. Invest. 97, 1916-1923

35 Chan, W. L., Shaw, P. C., Tam, S. C., Jacobsen, C., Gliemann, J. and Nielsen, M. S (2000) Trichosanthin interacts with and enters cells via LDL receptor family members. Biochem. Biophys. Res. Commun. 270, 453-457

36 Zhao, J., Ben, L. H., Wu, Y. L., Hu, W., Ling, K., Xin, S. M., Nie, H. L., Ma, L. and Pei, G. (1999) Anti-HIV agent trichosanthin enhances the capabilities of chemokines to stimulate chemotaxis and $\mathrm{G}$ protein activation, and this is mediated through interaction of trichosanthin and chemokine receptor. J. Exp. Med. 190, 101-111

37 Goldman, R., Moshonov, S. and Zor, U. (1999) Calcium-dependent PAF-stimulated generation of reactive oxygen species in a human keratinocyte cell line. Biochim. Biophys. Acta 1438, 349-358

38 Volk, T., Hensel, M. and Kox, W. (1997) Transient $\mathrm{Ca}^{2+}$ changes in endothelial cells induced by low doses of reactive oxygen species: role of hydrogen peroxide. Mol. Cell Biochem. 171, 11-21

39 Kawakami, M. and Okabe, E. (1998) Superoxide anion radical-triggered $\mathrm{Ca}^{2+}$ release from cardiac sarcoplasmic reticulum through ryanodine receptor $\mathrm{Ca}^{2+}$ channel. Mol. Pharmacol. 53, 497-503

40 Burlando, B., Viarengo, A., Pertia, M., Ponzano, E. and Oranesco, M. (1997) Effects of free oxygen radicals on $\mathrm{Ca}^{2+}$ release mechanisms in the sarcoplasmic reticulum of scallop (Pecten jacobaeus) adductor muscle. Cell Calcium 22, 83-90

41 Clapham, D. E. (1995) Calcium signaling. Cell 80, 259-268

42 Bygrave, F. L. and Roberts, H. R. (1995) Regulation of cellular calcium through signaling cross-talk involves an intricate interplay between the actions of receptors, G-proteins, and second messengers. FASEB J. 9, 1297-1303

43 Chen, Y. C., Lin-Shiau, S. Y. and Lin, J. K. (1998) Involvement of reactive oxygen species and caspase 3 activation in arsenite-induced apoptosis. J. Cell Physiol. 177, 324-333

44 Muschel, R. J., Bernhard, E. J., Garza, L., McKenna, W. G. and Koch, C. J. (1995) Induction of apoptosis at different oxygen tensions: evidence that oxygen radicals do not mediate apoptotic signaling. Cancer Res. 55, 995-998

45 Alnemri, E. S. and Litwack, S. (1990) Activation of internucleosomal DNA cleavage in human CEM lymphocytes by glucocorticoid and novobiocin. Evidence for a non-Ca ${ }^{2+}$. requiring mechanism. J. Biol. Chem. 265, 17323-17333

46 Stefanis, L., Park, D. S., Friedman, W. J. and Greene, L. A. (1999) Caspase-dependent and -independent death of camptothecin-treated embryonic cortical neurons. J. Neurosci. 19, 6235-6247

47 Garcia, P. A., Bredesen, D. E., Vinters, H. V., Graefin von Einsiedel, R., Williams, R. L., Kahn, J. O., Byers, V. S., Levin, A. S., Waites, L. A. and Messing, R. O. (1993) Neurological reactions in HIV-infected patients treated with trichosanthin. Neuropathol. Appl. Neurobiol. 19, 402-405

Received 30 October 2000/18 January 2001; accepted 13 February 2001 